\title{
IMPACT OF $\mathrm{SO}_{2}$ SHIPPING EMISSIONS ON AIR QUALITY: THE AIRSHIP PROJECT
}

\author{
ALEXANDRA MONTEIRO, MICHAEL RUSSO, CARLA GAMA \& CARLOS BORREGO \\ CESAM \& Department of Environment and Planning, University of Aveiro, Portugal
}

\begin{abstract}
Due to its dependence on fossil fuel combustion, emissions from the marine transport sector can significantly contribute to air pollution. The AIRSHIP research project (http://airship.web.ua.pt/) aims to evaluate this contribution and how it affects air quality in Europe, and over Portugal in particular, using a numerical air quality modelling approach with high-resolution emission data. Emissions from the MACC project inventory were compiled and pre-processed at hourly and high spatial resolutions. Scenarios with and without the maritime emissions were then simulated with the WRF-CHIMERE modelling system, amply tested and validated for both simulation domains, in order to evaluate its impact on air quality. This modelling system was applied for Europe $\left(27 \times 27 \mathrm{~km}^{2}\right)$ and Portugal $(3 \times 3$ $\mathrm{km}^{2}$ ) domains, using nesting approach. The talk will focus on presenting part of the work of the research project, namely regarding the comparison of the modelling results (with and without considering maritime emissions) for Europe and Portugal domains, with focus on $\mathrm{SO}_{2}$ pollutant, one of the most critical pollutants associated to shipping activity. The main differences/impacts for $\mathrm{SO}_{2}$ are located over the international shipping routes and major ports. The modelling results also indicate that the two main hotspots areas are located in the Baltic and Mediterranean Sea. Over Portugal domain, the impact of these maritime emissions reaches the coast and is responsible for deltas of $\mathrm{SO}_{2}$ superior to $2 \mu \mathrm{g} . \mathrm{m}^{-3}$.

Keywords: $\mathrm{SO}_{2}$ pollutant, emissions, shipping, air quality modelling, Portugal.
\end{abstract}

\section{INTRODUCTION}

Maritime transport is an important sector in Europe that enables trade and contact between all European nations. Almost $90 \%$ of the external freight trade in the EU is seaborne [1]. This form of transportation has also been increasing due to the globalization of manufacturing processes and the increase of global-scale trade [2]-[4]. However, emissions from the marine transport sector can have a considerable impact on atmospheric concentrations of several important pollutants, especially in coastal areas [5]-[11]. The most important are carbon dioxide $\left(\mathrm{CO}_{2}\right)$, nitrogen oxides $\left(\mathrm{NO}_{\mathrm{x}}\right)$, sulphur dioxide $\left(\mathrm{SO}_{2}\right)$, carbon monoxide $(\mathrm{CO})$, hydrocarbons, and primary and secondary particulates [12].

Approximately $15 \%$ of global anthropogenic $\mathrm{NO}_{x}$ and $58 \%$ of global $\mathrm{SO}_{x}$ emissions are attributable to oceangoing ships [2], [13]. Because nearly $70 \%$ of ship emissions are estimated to occur within $400 \mathrm{~km}$ of land [7], ships have the potential to contribute significantly to air quality degradation in coastal areas.

During the last two decades large efforts have been made in Europe to reduce other types of emission sources (industrial, power generation, etc.), and this results in an increase of the relative weight of shipping emissions to total anthropogenic emissions [12]. It is therefore important to understand atmospheric impacts of these emissions, especially on regional air quality.

Corbett et al. [2] have recently shown that ship emissions lead to an increase in ambient air concentrations of fine particles with a diameter less than $2.5 \mu \mathrm{m}$ (PM2.5) and therefore are responsible for an increase of premature deaths due to cardiopulmonary diseases and lung cancer [14]. Vutukuru and Dabdub [15] evaluates the impacts of ship emissions on ambient ozone and PM concentrations over California for the first time. Lawrence and Crutzen [6] showed an increase in surface ozone and $\mathrm{OH}$ radical concentrations when $\mathrm{NO}_{\mathrm{x}}$ emissions 
from ships are included in a global chemistry transport model. Similarly, [16] calculated an increase of $\mathrm{SO}_{2}$ concentrations as high as $60 \%$ when sulphur emissions from ships are included in a global model. Ship emissions also lead to an increase in aerosol production through enhancement of $\mathrm{OH}$ radical concentration. A 30\% increase in sulphate aerosol is predicted due to sulphur emission from ships [16]. Streets et al. [17] concluded that parts of Southeast Asia receive significant amounts of sulphur deposition due to ship emissions. A maximum perturbation of $12 \mathrm{ppb}$ for tropospheric ozone concentrations was found by [7] at a global scale study. Derwent et al. [18] applied a Lagrangian chemistry-transport model and showed that contribution of ships to sulphur deposition is as high as $55 \%$ for some locations in Europe.

Most of the previous studies have dealt with the impacts of ship emissions on a global and continental scale, using global models with coarse horizontal resolutions [19]-[21] and relatively few studies have dealt with the impacts of ship emissions in detail [2], [21]-[24]. This makes it rather difficult to estimate the effects of ship emissions on coastal areas and on the resident population. There is a still lack of knowledge at finer scales, over recent years (when more restrict policy exist for shipping emissions) and including all type of pollutants (primary and secondary as ozone, particularly critical in southern European areas).

The ongoing AIRSHIP project (http://airship.web.ua.pt/) intends to assess the impact of shipping emissions on the air quality over Portugal and to design effective regulation to minimise environmental impacts of these emissions. The present work is part of this research project and bridges that gap by conducting a modelling study for Portugal region, where several important and large ports near urban airsheds exist. In this study, we investigated the impacts of current ship emissions on the air quality over Europe and, in particular, over Portugal, using a numerical air quality modelling system, extensively validated, and focusing on $\mathrm{SO}_{2}$ pollutant, one of the main critical pollutants for this source activity.

The paper is organised as follows. In Section 2, the modelling approach is described in detail. Section 3 focuses on the analysis of the results and the assessment of the air quality impact. Finally, in Section 4, the main conclusions are summarized.

\section{THE MODELLING SYSTEM AND ITS SETUP}

Numerical modelling has become a fundamental tool to support decision makers on air quality management due to its capacity to estimate atmospheric pollutants concentrations over the entire region of interest, taking into account complex and non-linear physic and chemical mechanisms that characterize the atmosphere, as well as to evaluate the efficiency of emission scenarios. A mesoscale numerical modelling system was selected and applied in the present study to investigate the effects of shipping emissions on the air quality over Portugal. Following is a detailed description of the modelling system and its application.

\subsection{The WRF-CHIMERE modelling system}

The air quality modelling system includes the Weather Research and Forecasting (WRF, version 3.5.0) model (WRF) [25] and the CHIMERE chemical transport model [26], [27] (as shown in Fig. 1). The WRF model was developed by the National Center for Atmospheric Research (NCAR) and is a next generation mesoscale numerical weather prediction system designed to serve both operational forecasting and atmospheric research needs. CHIMERE is a comprehensive Eulerian air quality modelling system in a non-hydrostatic configuration. Its nesting facility enables to telescope from $1,000 \mathrm{~km}$ to $1 \mathrm{~km}$ of horizontal resolution, allowing the combination of both high grid resolutions and the representation of large-scale 


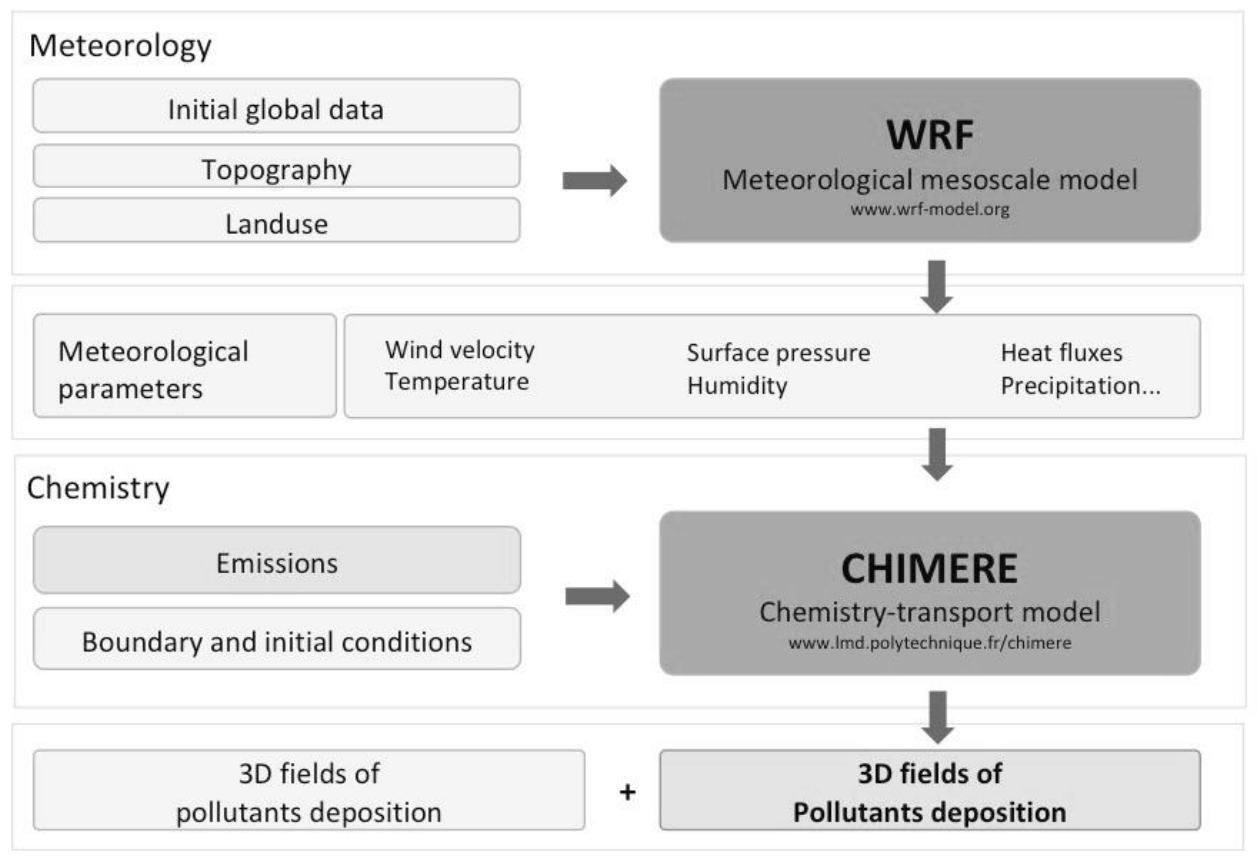

Figure 1: The modelling system WRF-CHIMERE applied in this study.

transport processes and long-term simulations for emission control scenarios. This modelling system has been extensively used for Europe and in particular Portugal domain [28]-[30] and is being used as the operational modelling system for daily air quality forecast (http://previsao-qar.web.ua.pt/).

\subsection{Modelling setup and application}

The WRF-CHIMERE simulations used three different spatial domains in order to reach a high-resolution scale over Portugal, using nesting capabilities. At first, a grid with a large extent, continental scale, covering Southern Europe with a low horizontal resolution of $27 \times 27$ $\mathrm{km}^{2}$ (CONT27, the coarse domain); then a second domain covering the Iberian Peninsula with $9 \times 9 \mathrm{~km}^{2}$ of horizontal resolution (IP09) and then the last high-resolution domain covers mainland Portugal, with $3 \times 3 \mathrm{~km}^{2}$ (PT03). The different simulation domains are geographically represented in Fig. 2.

Regarding the vertical resolution, all the domains are divided into 23 terrain-following sigma coordinate layers. The top boundary of the WRF-CHIMERE is set at $100 \mathrm{hPa}$ and the diffuse vertical fluxes at the top are set to zero. Approximately 15 layers are defined above 2 $\mathrm{km}$ and the Earth's surface is the bottom boundary.

Regarding the meteorological forcing, the WRF model was applied with parameterizations selection based on recommendations included in [9] as well as on validation and sensitivity studies previously performed over Portugal [31] and over the Iberian Peninsula [32], namely for microphysics, cumulus parameterization and radiation, land-surface and planetary boundary layer schemes. 


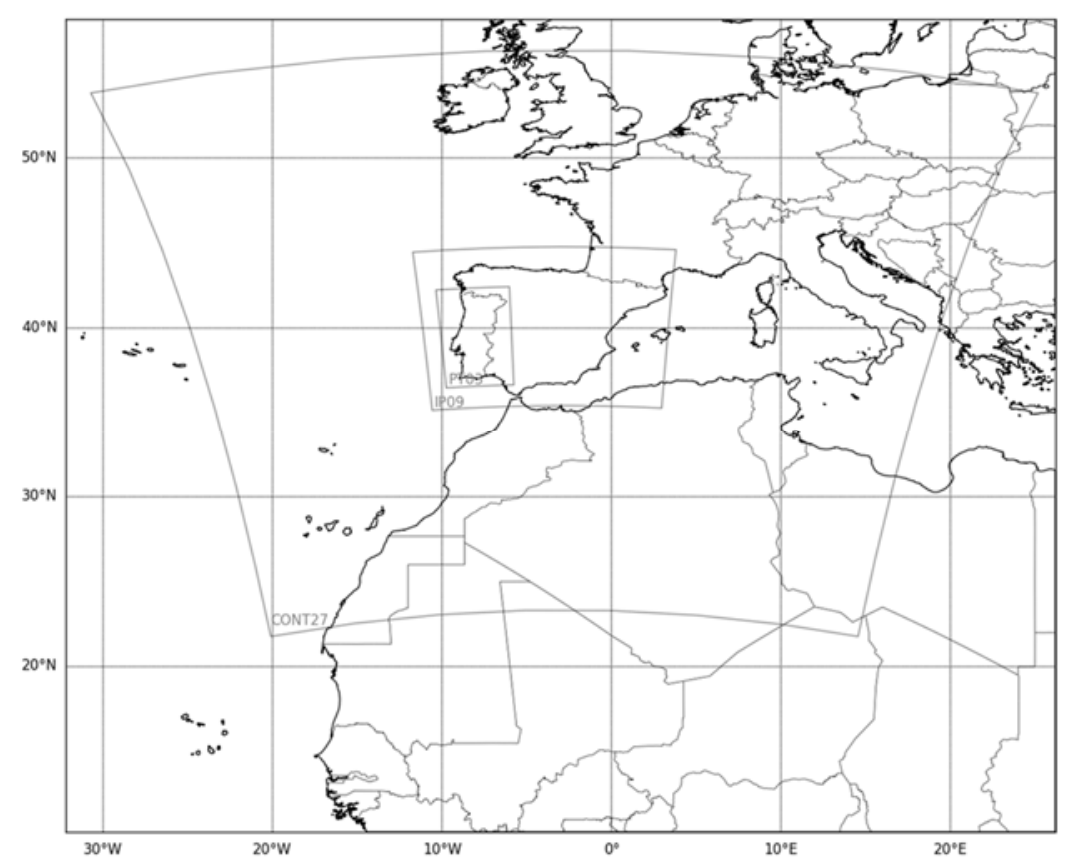

Figure 2: Simulation domains defined for the WRF-CHIMERE modelling application.

The global meteorological fields from the National Center for Environmental Prediction (NCEP/NOAA, 2000), which provide final operational global data on $1^{\circ}$ by $1^{\circ}$ grids with a temporal resolution of six hours, were used to supply initial and boundary conditions for the coarse domain (CONT27), while for the other domains, the initial and boundary conditions come from the respective parent domain and from the previous simulated day. More details in modelling setup and validation can be seen in [30] and [33].

This modelling system was applied for 2015, coupled with the most updated emission inventory available. Emission data from the TNO-MACC_III inventory were used, since it is the highest spatially resolved emissions source available for Europe $\left(0.125^{\circ} \times 0.0625^{\circ}\right.$ gridded) with the complete set of emission sectors [34]. This emissions inventory provides anthropogenic emissions data by country and by source category (including shipping), combining the emissions data officially reported by the countries to EMEP, information at country level from the IIASA GAINS model and expert estimates [35].

Fig. 3 presents the total $\mathrm{SO}_{2}$ emissions, per activity sector, compiled in this emission inventory for Europe and Portugal domains. The reference year is 2015.

The main contributor's sectors for $\mathrm{SO}_{2}$ in Europe are the energy production (S1) - with more than 50\%, industry sector (S3 and S4) and shipping (S8), with a relative percentage of $17 \%$. This scenario is very different for the specific case of Portugal: the main contributors are first industry sector (49\%) and secondly the maritime transport (with 31\%). This is explained by the location and relevant coastal area of this country, where shipping activity is even more important than in other European states.

Fig. 4 shows the spatial distribution of these $\mathrm{SO}_{2}$ emissions, according to the resolution of the emission inventory, for both Europe and Portugal domains. 

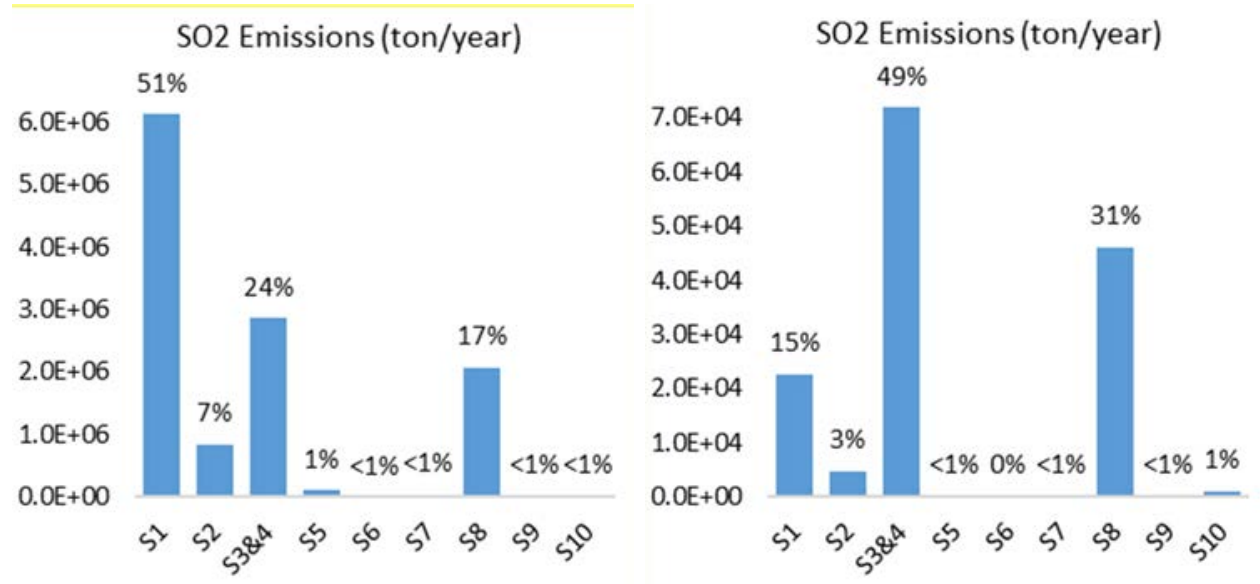

Figure 3: $\quad \mathrm{SO}_{2}$ emissions per activity sector for Europe (left) and Portugal (right) in tonnes per year.
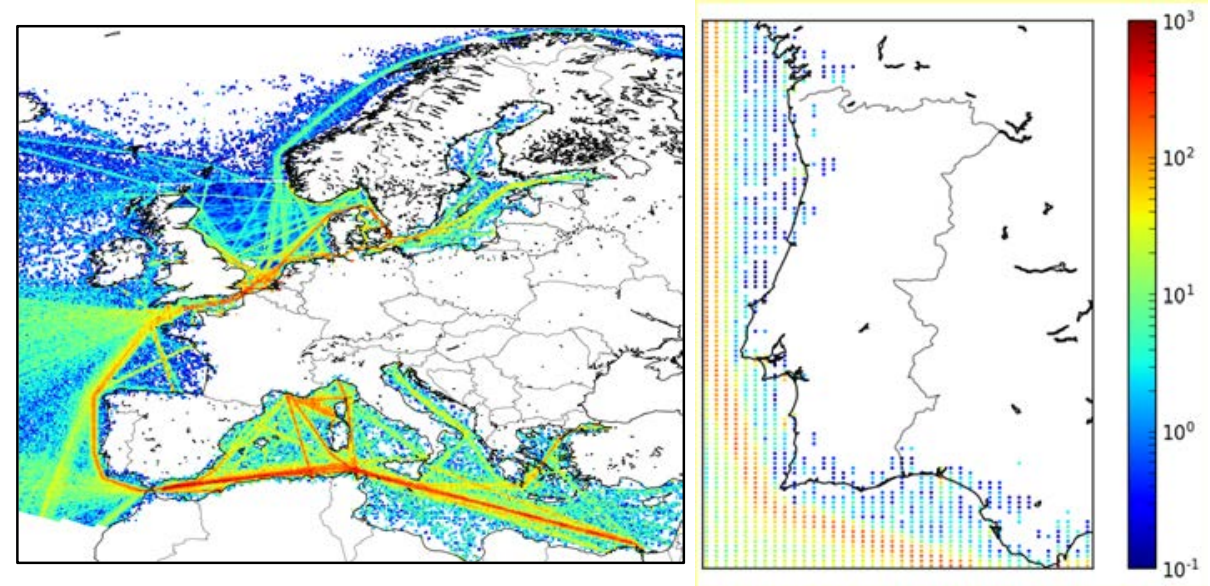

Figure 4: $\mathrm{SO}_{2}$ emissions from shipping over Europe (left) and Portugal (right) domains in tonnes per year.

The maps of Fig. 4 indicates that the main contributor's areas in terms of $\mathrm{SO}_{2}$ shipping emissions are the Mediterranean sea and the Atlantic North. The Baltic sea was in previous years the main hotspot in terms of shipping emissions, but due to severe local restrictions related to the use of fuel, these $\mathrm{SO}_{2}$ emissions have been reduced in the last 5 years. Regarding Portugal domain, emissions are mainly restricted to the main international shipping routes, which in some areas are close to the coast (southwest).

\section{IMPACT OF SHIPPING EMISSIONS ON AIR QUALITY}

In order to evaluate and quantify the contribution of the $\mathrm{SO}_{2}$ emissions of the shipping sector on air quality, the modelling results for the differences scenarios (with and without shipping 
emissions) were analysed in terms of spatial distribution (delta analysis) and regarding time series, for specific locations.

Fig. 5 show the spatial distribution of differences (mean and maximum) found between the simulations with and without maritime emissions, for the European Portugal domains, and regarding $\mathrm{SO}_{2}$.

Over the European domain, there are two regions where the difference is maximum (with deltas superior to $27 \mu \mathrm{g} \cdot \mathrm{m}^{-3}$ ): the Mediterranean and North seas. Regarding the mean differences, they reach $8 \mu \mathrm{g} \cdot \mathrm{m}^{-3}$ for $\mathrm{SO}_{2}$. These mean deltas are of the same order of magnitude as the annual averages of the $\mathrm{SO}_{2}$ pollutant over the European domain (EEA, 2017): $<10 \mu \mathrm{g} . \mathrm{m}^{-3}$. The differences are almost restricted to international shipping routes and major ports. The impact is registered mainly over the coast and up to few kilometers inland. Over Portugal, the shipping contribution is, on average, only $4 \mu \mathrm{g} . \mathrm{m}^{-3}$ but with maximums of $24 \mu \mathrm{g} \cdot \mathrm{m}^{-3}$.

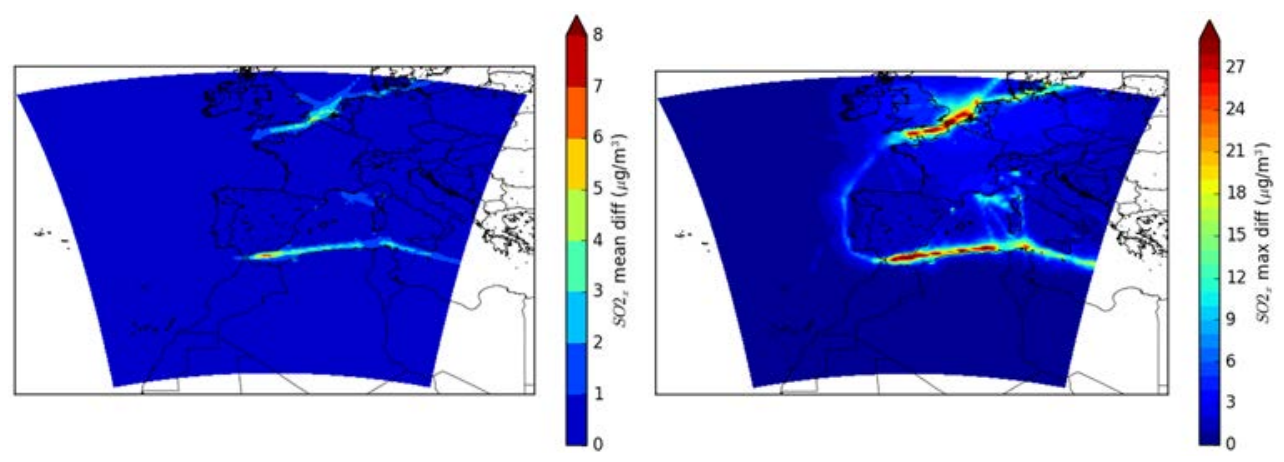

(a)
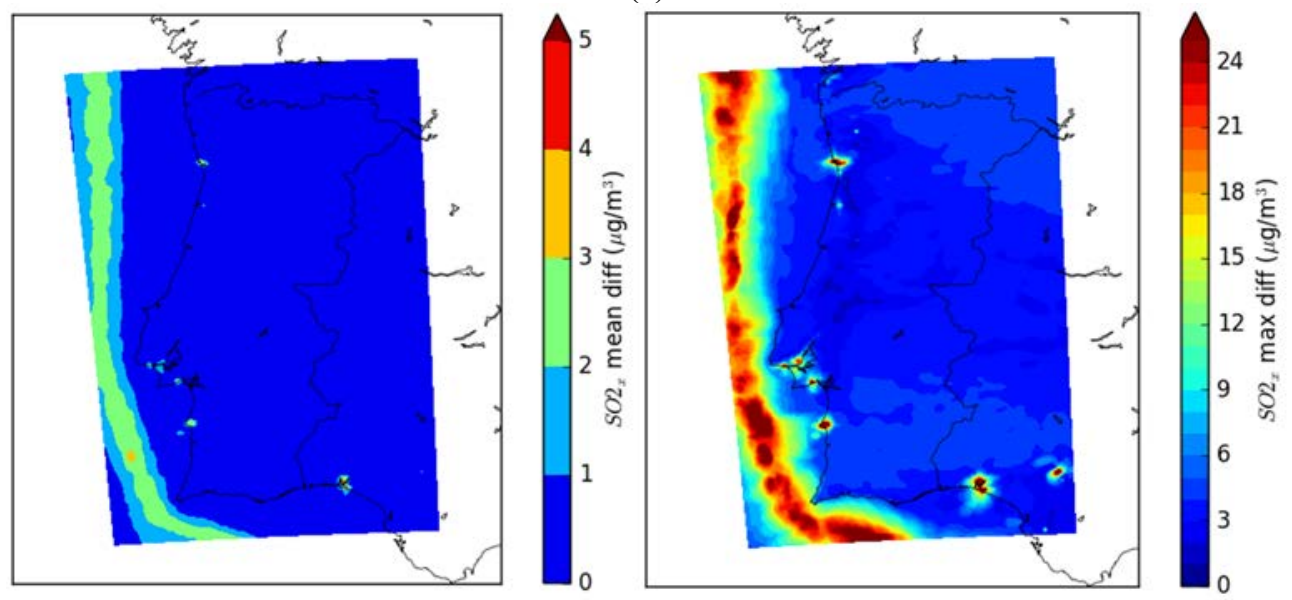

(b)

Figure 5: Mean deltas (left) and maximum deltas (right) between the simulations - with and without shipping emissions - for $\mathrm{SO}_{2}$ concentrations, for the European; (a) and Portugal; (b) domains. 


\section{SUMMARY AND CONCLUSIONS}

This study investigates the impact of shipping emissions on the air quality over Europe and, in particular, Portugal, focusing on $\mathrm{SO}_{2}$ concentrations. For that, a numerical modelling approach was used to simulate this impact. Emissions from the TNO inventory were processed for the defined modelling resolution $\left(3 \times 3 \mathrm{~km}^{2}\right.$ over the Portugal finest domain). Modelling results point out that the most critical areas in Europe occur in the North and Mediterranean Seas, limited to the international route. The main differences for $\mathrm{SO}_{2}$ are located over the international shipping routes and major ports. The impacted area extended over the entire west and south coast with deltas higher than $8 \mu \mathrm{g} \cdot \mathrm{m}^{-3}$ (on average) and $28 \mu \mathrm{g} \cdot \mathrm{m}^{-3}$ (maximums). Over Portugal domain there are deltas of $4 \mu \mathrm{g} \cdot \mathrm{m}^{-3}$, with maximums higher than $24 \mu \mathrm{g} \cdot \mathrm{m}^{-3}$.

These modelling results will aid the management and political actions in the maritime transport sector and its environmental impacts, specifically concerning the maritime transport and port sectors. In the future, plans will include the study of these impacts considering climate change scenarios.

\section{ACKNOWLEDGEMENTS}

Thanks are due for the financial support to FCT/MEC through national funds, and the cofunding by the FEDER, within the PT2020 Partnership Agreement and Compete 2020, for the AIRSHIP project (PTDC/AAG-MAA/2569/2014 - POCI-01-0145-FEDER-016752) and CESAM (UID/AMB/50017 - POCI-01-0145-FEDER-007638).

\section{REFERENCES}

[1] Jonson, J.E., Jalkanen, J.P., Johansson, L., Gauss, M. \& Denier van der Gon, H.A.C., Model calculations of the effects of present and future emissions of air pollutants from shipping in the Baltic Sea and the North Sea. Atmospheric Chemistry \& Physics, 15, pp. 783-798, 2015.

[2] Corbett, J.J., Winebrake, J.J., Green, E.H., Kasiblathe, P., Eyring, V. \& Lauer, A., Mortality from ship emissions: A global assessment. Environmental Science Technology, 41, pp. 8512-8518, 2007.

[3] Marmer, E. et al., What can we learn about ship emission inventories from measurements of air pollutants over the Mediterranean Sea? Atmospheric Chemistry \& Physics, 9, pp. 6815-6831, 2009.

[4] Viana, M. et al., Impact of maritime transport emissions on coastal air quality in Europe. Atmospheric Environment, 90, pp. 96-105, 2014.

[5] Aulinger, A., Matthias, V., Zeretzke, M., Bieser, J., Quante, M. \& Backes, A., The impact of shipping emissions on air pollution in the greater North Sea region - Part 1: Current emissions and concentrations. Atmospheric Chemistry \& Physics, 16, pp. 739$758,2016$.

[6] Lawrence, M.G. \& Crutzen, P.J., Influence of $\mathrm{NO}_{\mathrm{x}}$ emissions from ships on tropospheric photochemistry and climate. Nature, 402(6758), pp. 167-170, 1999.

[7] Endresen, Ø. et al., Emission from international sea transportation and environmental impact. Journal of Geophysical Research, 108 (D17), p. 4560, 2003.

[8] Marmer, E. \& Langmann, B., Impact of ship emissions on the Mediterranean summertime pollution and climate: a regional model study. Atmospheric Environment 39, pp. 4659-4669, 2005.

[9] Wang, C., Corbett, J.J. \& Firestone, J., Improving spatial representation of global ship emissions inventories. Environ. Sci. Technol., 42, pp. 193-199, 2008. 
[10] Matthias, V., Bewersdorff, I., Aulinger, A. \& Quante, M., The contribution of ship emissions to air pollution in the North Sea regions. Environmental Pollution, 158, pp. 2241-2250, 2010.

[11] Gonzalez, Y., Rodriguez, S., Guerra Garcìa, J.C., Trujillo, J.L. \& Garcìa, R., Ultrafine particles pollution in urban coastal air due to ship emissions. Atmospheric Environment, 45, pp. 4907-4914, 2011.

[12] EEA, The Impact of International Shipping on European Air Quality and Climate Forcing, EEA: Copenhagen, p. 88, 2013.

[13] Eyring, V., Kohler, H.W., van Aardenne, J. \& Lauer, A., Emissions from international shipping: 1. The last 50 years. Journal of Geophysical Research Atmos., 110, D17305, 2005.

[14] Winebrake, J.J., Corbett, J.J., Green, E.H., Lauer, A. \& Eyring, V., Mitigating the health impacts of pollution from oceangoing shipping: an assessment of low sulfur fuel mandates. Environmental Science \& Technology, 43(13), pp. 4776-4782, 2009.

[15] Vutukuru, S. \& Dabdub, D., Modeling the effects of ship emissions on coastal air quality: A case study of southern California. Atmospheric Environment, 42, pp. 37513764, 2008.

[16] Capaldo, K., Corbett, J.J., Kasibhatla, P., Fischbeck, P. \& Pandis, S.N., Effects of ship emissions on sulphur cycling and radiative climate forcing over the ocean. Nature, 400, pp. 743-746, 1999.

[17] Streets, D.G. et al., The growing contribution of sulfur emissions from ships in Asian Waters 1988-1995. Atmospheric Environment, 24(26), pp. 4425-4439, 2000.

[18] Derwent, R.G. et al., The contribution from shipping emissions to air quality and acid deposition in Europe. Ambio, 34(1), pp. 54-59, 2005.

[19] Dalsøren, S.B., Endresen, Ø., Isaksen, I.S.A., Gravir, G. \& Sørgård, E., Environmental impacts of the expected increase in sea transportation, with a particular focus on oil and gas scenarios for Norway and northwest Russia. Journal of Geophysical Research - Atmospheres, 112 (D2), D02310, 2007.

[20] Collins, B., Sanderson, M.G. \& Johnson, C.E., Impact of increasing ship emissions on air quality and deposition over Europe by 2030. Meteorologische Zeitschrift, 18(1), pp. 25-39, 2009.

[21] Aksoyoglu, S., Baltensperger, U. \& Prévôt, A., Contribution of ship emissions to the concentration and deposition of air pollutants in Europe. Atmospheric Chemistry \& Physics, 16, pp. 1895-1906, 2016.

[22] Eyring, V. et al., Transport impacts on atmosphere and climate: shipping. Atmospheric Environment, 44, pp. 4735-4771, 2010.

[23] Huszar, P. et al., Modeling the regional impact of ship emissions on $\mathrm{NO}_{\mathrm{x}}$ and ozone levels over the Eastern Atlantic and Western Europe using ship plume parameterization. Atmospheric Chemistry \& Physics, 10, pp. 6645-6660, 2010.

[24] Jonson, J.E., Tarrason, L., Klein, H., Vestreng, V., Cofala, J. \& Whall, C., Effects of ship emissions on European ground-level ozone in 2020. International Journal of Remote Sensing, 30(15-16), pp. 4099-4110, 2009.

[25] Skamarock, W.C. \& Klemp, J.B., A time-split nonhydrostatic atmospheric model for weather research and forecasting applications. Journal Computational Physics, 227, pp. 3465-3485, 2008.

[26] Menut, L. et al., CHIMERE 2013: a model for regional atmospheric composition modelling. Geoscientific Model Development, 6, pp. 981-1028, 2013.

[27] Mailler, S. et al., CHIMERE-2017: from urban to hemispheric chemistry-transport modeling. Geoscience Model Development, 10, pp. 2397-2423, 2017. 
[28] Monteiro, A., Vautard, R., Borrego, C. \& Miranda, A.I., Long-term simulations of photo oxidant pollution over Portugal using the CHIMERE model. Atmospheric Environment, 39, pp. 3089-3101, 2005.

[29] Monteiro, A., Miranda, A.I., Borrego, C., Vautard, R., Ferreira, J. \& Perez, A.T., Longterm assessment of particulate matter using CHIMERE model. Atmospheric Environment, 41, pp. 7726-7738, 2007.

[30] Borrego, C. et al., How bias-correction can improve air quality forecast over Portugal. Atmospheric Environment, 45(37), pp. 6629-6641, 2011.

[31] Carvalho, A.C. et al., Influence of topography and land use on pollutants dispersion in the Atlantic coast of Iberian Peninsula. Atmospheric Environment, 40, pp. 3969-3982, 2006.

[32] Fernández, J., Montávez, J.P., Sáenz, J., González-Rouco, J.F. \& Zorita, E., Sensitivity of the MM5 mesoscale model to physical parameterizations for regional climate studies: Annual cycle. Journal of Geophysical Research, 112, D04101, 2007.

[33] Monteiro, A. et al., Bias correction techniques to improve air quality ensemble predictions: focus on $\mathrm{O}_{3}$ and $\mathrm{PM}$ over Portugal. Environmental Modelling \& Assessment, 18(5), pp. 533-546, 2013.

[34] Russo, M.A., Leitão, J., Gama, C., Ferreira, J., Borrego, C. \& Monteiro, A., Shipping emissions over Europe: a state-of-the-art and comparative analysis. Atmospheric Environment, 177, pp. 187-194, 2018.

[35] Kuenen, J.J.P., Visschedijk, A.J.H., Jozwicka, M. \& Denier van der Gon, H.A.C., TNO-MACC_II emission inventory: a multi-year (2003-2009) consistent highresolution European emission inventory for air quality modelling. Atmospheric Chemistry \& Physics, 14, pp. 10963-10976, 2014. 